\title{
INDEKS GLIKEMIK BAHAN MAKANAN DENGAN KADAR GLUKOSA DARAH PADA PENDERITA DIABETES MELLITUS TIPE 2 DI PUSKESMAS RANOTANA WERU
}

\author{
Nita R. Momongan ${ }^{1, a}$, Phembriah S. Kereh ${ }^{2, a}$, dan Sasauw Sriwartini ${ }^{3}$ \\ ${ }^{123}$ Jursan Gizi Poltekkes Kemenkes Manado Idonesia

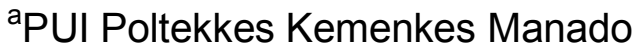 \\ nitarianymomongan@gmail.com
}

\begin{abstract}
The food glycemic index is a scale or number of foodstuffs that if consumed can have an impact on blood glucose levels so it can be used as a way to control blood glucose levels. The purpose of this study to determine the relationship of glycemic index of food with blood glucose level at diabetes mellitus type 2 in working area of Ranotana Weru Health Center. This research is an observational research using cross sectional research design with sample consist of 34 respondents who fill up the criteria of inclusion and exclusion. Data retrieval is done through interviews using food frequency questionnaire form (FFQ) and blood glucose levels obtained from the examination using autocek. Univariate analysis is done by frequency distribution and bivariate analysis using Fisher's Exact Test. The results showed that of 34 respondents most of the respondents have blood glucose levels when the uncontrolled $\geq 180 \mathrm{mg} / \mathrm{dl}$ and consumed a high food glycemic indexs of 28 respondents (82,3\%). While respondents have controled blood glucose levels of $<180$ $\mathrm{mg} / \mathrm{dl}$ and consumed a low food glycemic index is 5 respondents (14,7\%). Average blood glucose levels of respondents is $237,74 \% \mathrm{mg} / \mathrm{dl}$. The statistical test is done obtained that there was correlation of food glycemic index with blood glucose level with value $p=0,000$ ( $p$ $<0,05)$. Conclusion, there is correlation of food glycemic index with blood glucose level in type 2 diabetes mellitus in working area of Ranotana Weru Health Center.
\end{abstract}

Keywords: Food Glycemic Index, Blood Glucose Level, Diabetes Mellitus type 2

\section{PENDAHULUAN}

Indonesia merupakan salah satu dari negara berkembang yang memiliki berbagai masalah kesehatan, salah satunya yaitu diabetes melitus. WHO (2016) menyatakan pada tahun 2012 ada 1,5 miliar orang meninggal karena penyakit diabetes melitus dan pada tahun 2014 masyarakat dengan usia 18 tahun sudah menderita penyakit diabetes melitus dengan prevalensi 8,5\%. Negara Eropa pada tahun 2014 ada 60 milyar orang menderita penyakit diabetes melitus dengan $10,3 \%$ penderitanya laki-laki dan $9,6 \%$ perempuan pada usia 25 tahun keatas.

Data Riskesdas tahun 2013, menunjukan prevalensi diabetes melitus pada usia $>15$ tahun di Indonesia yang terdiagnosis dengan gejala sebesar 2,1\%. Propinsi Sulawesi utara memiliki prevalensi diabetes melitus yang terdiagnosis dengan gejala yaitu $3,6 \%$. Sedangkan kota Manado memiliki prevalensi diabetes melitus yaitu $3,8 \%$.

Diabetes melitus merupakan penyakit endokrin yang paling banyak ditemukan. Diabetes melitus memiliki beberapa klasifikasi salah satunya diabetes melitus tipe 2. Sekarang ini penyakit diabetes melitus dapat diketahui dengan melakukan pemeriksaan kadar glukosa darah salah satunya yaitu kadar glukosa 
darah sewaktu. Penyakit diabetes melitus harus dilakukan upaya terhadap pengendalian kadar glukosa darah cara yang dapat digunakan yaitu dengan memperhatikan makanan yang akan dikonsumsi seperti memperhatikan indeks glikemik bahan makanan yang akan dikonsumsi. Indeks glikemik bahan memiliki kategori rendah, sedang dan tinggi. Memperhatikan indeks glikemik bahan makanan yang akan dikonsumsi nantinya akan membantu dalam upaya pengendalian kadar glukosa darah penderita diabetes melitus tipe 2. Berdasarkan survei diperoleh rata-rata penderita diabetes melitus yang berkunjung ke Puskesmas Ranotana Weru pada bulan Januari sampai Maret yaitu 71 orang.

Berdasarkan latar belakang masalah maka dapat diambil rumusan masalah penelitian apakah ada hubungan indeks glikemik bahan makanan dengan kadar glukosa darah pada penderita diabetes melitus tipe 2 di wilayah kerja Puskesmas Ranotana Weru.

Tujuan penelitian ini untuk mengetahui hubungan indeks glikemik bahan makanan dengan kadar glukosa darah pada penderita diabetes melitus tipe 2 di wilayah kerja Puskesmas Ranotana Weru.

\section{METODE}

Penelitian ini merupakan penelitian jenis observasional dengan desain penelitian cross sectional. Penelitian ini dilakukan pada bulan Maret sampai Mei tahun 2018. Tempat penelitian di wilayah kerja Puskesmas Ranotana Weru yang merupakan salah satu puskesmas di Kota Manado.

Populasi penelitian ini adalah semua pasien diabetes melitus tipe 2 yang berkunjung di Puskesmas Ranotana Weru di wilayah kerja Puskesmas Ranotana Weru. Penelitian ini, menggunakan teknik pengambilan sampel purposive sampling dan harus memenuhi kriteria sampai jumlah sampel yang perlukan. Responden dalam penelitian ini berjumlah 34 responden, yang kemudian setelah mendapatkan persetujuan di lakukan wawancara tentang identitas responden lalu diukur kadar glukosa darah sewaktu yaitu autocek kemudian di lakukan wawancara dengan menggunakan formulir food frequency questionnaire (FFQ) untuk mengetahui kebiasaan konsumsi responden tentang indeks glikemik bahan makanan.

Analisis data yang digunakan adalah analisis univariat dan bivariate. Analisis univariat dilakukan terhadap tiap variabel dari hasil penelitian dengan menggunakan tabel distribusi frekuensi. Analisis bivariat dilakukan untuk mengetahui untuk mengetahui hubungan variabel bebas (independent) yakni indeks glikemik bahan makanan dan variabel dependent (terikat) yaitu kadar glukosa darah sewaktu. Analisis bivariat menggunakan Fisher's Exact Test.

\section{HASIL}

Hasil penelitian menunjukkan bahwa bahwa responden paling banyak yaitu sebagai IRT sebanyak 14 responden $(41,2 \%)$ sedangkan yang paling sedikit yaitu responden dengan pekerjaan sebagai PNS, wiraswasta, TNI dan tukang ojek yang masing-masing berjumlah 1 responden $(2,9 \%)$ dan didapati hasil bahwa sebagian besar responden memiliki kadar glukosa darah sewaktu yang tidak terkendali $\geq 180 \mathrm{mg} / \mathrm{dL}$ yaitu 29 responden $(85,3 \%)$. Sedangkan responden yang 
memiliki kadar glukosa darah sewaktu yang terkendali $<180 \mathrm{mg} / \mathrm{dL}$ sebanyak 5 responden $(14,7 \%)$.

Hasil analisis pun yang dilakukan pada 34 responden menunjukan bahwa sebagian besar responden mengkonsumsi indeks glikemik bahan makanan yang tinggi dan memiliki kadar glukosa darah sewaktu yang tidak terkendali yaitu 28 responden (82,4\%). Sedangkan responden yang mengkonsumsi indeks glikemik bahan makanan yang rendah dan memiliki kadar glukosa darah yang terkendali sebanyak 5 responden $(14,7 \%)$. Analisis statistik dilakukan menggunakan uji Fisher's Exact Test diperolah hasil $p=0,000(p=<0,05)$, maka Ho ditolak, berarti terdapat hubungan indeks glikemik bahan makanan dengan kadar glukosa darah pada penderita diabetes melitus tipe 2 di wilayah kerja Puskesmas Ranotana Weru.

\section{PEMBAHASAN}

Penelitian yang dilakukan dengan 34 responden, menunjukan bahwa sebagian besar responden berjenis kelamin perempuan. Sehingga dapat dikatakan bahwa perempuan memiliki kecenderungan menderita penyakit diabetes melitus tipe 2 dibandingkan laki-laki. Hal ini berhubungan dengan riwayat kehamilan dan persalinan. Hasdiana (2012) menyatakan bahwa salah satu faktor resiko diabetes melitus tipe 2 yaitu sejarah diabetes gestasional atau kehamilan yang biasanya terjadi pada ibu hamil yang memiliki berat badan sebelum hamil $10 \%$ diatas berat badan ideal penggunaan steroid selama kehamilan.

Sedangkan menurut Fatimah (2015), dalam penelitiannya menyatakan bahwa riwayat persalinan menjadi salah satu resiko menderita diabetes melitus tipe 2 karena riwayat abortus berulang dan melahirkan bayi cacat atau berat badan bayi $>4000$ gram. Diabetes melitus tipe 2 juga dapat dipengaruhi oleh umur. Seperti yang diketahui bahwa semakin bertambahnya umur maka akan terjadi perubahan terhadap fungsi dari setiap organ tubuh. Penelitian ini keseluruhan responden memiliki umur diatas 40 tahun.

Suiraoka (2014), menyatakan bahwa semakin bertambahnya umur kemampuan jaringan mengambil glukosa darah semakin menurun sehingga menyebabkan diabetes melitus tipe 2 lebih banyak terdapat pada orang yang berumur di atas 40 tahun. Hal ini sejalan dengan penelitian yang dilakukan oleh Jelantik dan Haryati yang menyatakan bahwa 90\% responden diabetes melitus tipe 2 dari penelitian yang dilakukan memiliki umur diatas 40 tahun sedangkan $10 \%$ penderita diabetes melitus tipe 2 melimiki umur dibawah 40 tahun.

Selain jenis kelamin dan umur, jenis pekerjaan juga menjadi salah satu faktor yang mempengaruhi terjadinya penyakit diabetes melitus tipe 2 . Jenis pekerjaan berhubungan erat dengan tingkat dari pekerjaan yang dilakukan baik itu ringan, sedang atau beratnya pekerjaan. Dalam keadaan ini seseorang yang melakukan pekerjaan yang lebih banyak melakukan aktivitas maka akan mengakibatkan kontraksi otot yang pada akhirnya yang mempermudah glukosa untuk masuk ke sel. Sebagian besar responden dalam penelitian ini memiliki pekerjaan sebagai ibu rumah tangga (IRT). Dapat dikatakan ibu rumah tangga (IRT) lebih rentan menderita penyakit diabetes melitus tipe 2. Hal ini karena ibu rumah tangga (IRT) melakukan pekerjaan dengan aktifikas yang sedikit dan 
dilakukan secara berulang-ulang dan memiliki banyak waktu untuk berdiam diri dan santai. Nursam dkk (2017) dalam penelitian menyatakan bahwa dari 63 responden didapati 23 responden $(39,7 \%)$ memiliki pekerjaan sebagai ibu rumah tangga jumlah yang jauh lebih banyak dibandingkan dengan responden dengan pekerjaan lain. Begitu juga penelitian yang dilakukan oleh Mayawati dan Isnaeni (2017) dalam penelitiannya didapati bahwa dari 52 responden terdapat 18 responden $(34,6 \%)$ responden yang memiliki pekerjaan sebagai ibu rumah tangga jumlahnya lebih banyk dibandingkan responden yang memiliki pekerjaan lainnya.

Dalam penelitian ini sebagian besar reponden mengkonsumsi indeks glikemik bahan makanan yang tinggi sehingga menjadikan kadar glukosa darah sewaktu responden yang tidak terkendali. Arif, A, B. Budiyanto, A \& Hoerudin. (2013), menyatakan bahwa indeks glikemik merupakan skala atau angka yang diberikan pada bahan makanan tertentu berdasarkan seberapa cepat makanan tersebut meningkatkan kadar glukosa darahnya yang terdiri dari tiga kategori yaitu rendah, sedang dan tinggi.

Dari hasil analisis didapati bahwa terdapat hubungan antara indeks glikemik bahan makanan dengan kadar glukosa darah pada penderita diabetes melitus tipe 2. Indeks glikemik bahan makanan dapat berdampak pada menigkatnya kadar glukosa darah atau pun mengendalikan kadar glukosa darah.

Mengkonsumsi indeks glikemik bahan makanan yang rendah akan menghasilkan kadar glukosa darah yang lebih terkendali. Hal ini disebabkan karena proses pencernaan yang lambat sehingga laju pengosongan perut pun berlangsung lambat. Hal ini menyebabkan suspense bahan makanan lebih lambat mencapai usus kecil sehingga penyerapan glukosa pun semakin lebih lambat, tetapi sebaliknya jika mengkonsumsi indeks glikemik bahan makanan yang semakin tinggi maka laju pengosongan perut terjadi lebih cepat, penyerapan glukosa pun lebih cepat karena penyerapan glukosa terjadi hanya pada usus kecil bagian atas. Sejalan dengan penelitian yang dilakukan oleh Arif dkk (2013), menyatakan bahwa bahan makanan indeks glikemik tinggi memiliki penyerapan glukosa yang berlangsung cepat sehingga fluktasi kadar glukosa darah relatif akan tinggi dan tidak terkendali.

Menurut Hasdiana (2014), makan tinggi indeks glikemik cenderung meningkatkan glukosa darah dengan cepat serta dengan memilih makanan rendah indeks glikemik dapat membantu pengendalian kadar glukosa darah. Mayawati dan Isnaeni (2017), dalam penelitiannya menyatakan bahwa dari 12 responden didapati responden yang mengkonsumsi indeks glikemik bahan makanan yang rendah yang memiliki kadar glukosa darah yang normal dan terkendali yaitu 9 responden sedangkan yang mengkonsumsi indeks glikemik bahan makanan yang tinggi dan memiliki kadar glukosa darah yang tinggi dan tidak terkendali yaitu 3 responden.

Menurut Dalawa FN dkk (2013), dalam penelitiannya didapati bahwa terdapat hubungan dari indeks glikemik dan kontrol kadar glukosa darah penderita diabetes melitus tipe 2, karena rata-rata penderita mengkosumsi indeks glikemik yang masuk dalam kategori sedang memiliki kontrol kadar glukosa darah yang semakin buruk. Begitu juga dengan Isdiany dan Rosmana (2017) dalam penelitian menyatakan bahwa mengkonsumsi indeks glikemik yang tinggi 
mempunyak resiko lebih besar tidak berhasil mengendalikan kadar glukosa darah, sehingga penderita diabetes melitus dianjurkan untuk melakukan perencanaan makanan yang lebih baik dengan cara memperhatiak indeks glikemik bahan makanan yang akan dikonsumsi.

Indeks glikemik dapat menjadi salah satu cara dalam mengendalikan kadar glukosa darah atau pun sebaliknya tergantung dari setiap penderita diabetes melitus tipe 2 memilih mengkonsumsi indeks glikemik bahan makanan yang rendah, sedang atau pun yang tinggi. Tetapi anjuran terbaik untuk mengkonsumsi indeks glikemik bahan makanan yang rendah karena akan menghasilkan kadar glukosa darah yang lebih terkendali. Namun sekarang ini masih banyak penderita diabetes melitus tipe 2 yang masih mengkonsumsi indeks glikemik bahan makanan yang tinggi sehingga kadar glukosa darah menjadi tidak terkendali, seperti halnya yang terjadi pada penelitian sebagian besar sampel mengkonsumsi indeks glikemik bahan makanan yang tinggi sehingga kadar glukosa darah menjadi tinggi dan tidak terkendali.

\section{KESIMPULAN}

Sebagian besar responden dalam penelitian ini mengkonsumsi makanan dengan indeks glikemik bahan makanan tinggi, dan kadar glukosa darah sewaktu responden paling banyak masuk pada kategori tidak terkendali. Saran bagi penderita diabetes melitus tipe 2, sebaiknya lebih memperhatikan setiap bahan makanan yang akan dikonsumsi yaitu dengan memperhatikan indeks glikemik bahan makanan yang akan dikonsumsi sehingga dapat mengendalikan kadar glukosa darahnya.

\section{DAFTAR PUSTAKA}

Arif, A, B. Budiyanto, A \& Hoerudin. (2013). Nilai Indeks Glikemik Produk Pangan dan Faktor-Faktor Yang Mempengaruhinya. Jurnal Litbang Pertanian. Volume 32, Nomor 3. Bogor

Badan Penelitian dan Pengembangan Kesehatan Kementrian Kesehatan RI. (2013). Riset Kesehatan Dasar Nasional.

Dalawa FN, Kepel B, Hamel R. (2013) Hubungan antara status gizi dengan kadar gula darah puasa pada masyarakat Kelurahan Bahu Kecamatan Malayang Manado. Ejournal Keperawatan:1(1).

Fatimah, R. N. (2015). Diabetes melitus Tipe 2. J Majority. Volume 4, Nomor

Hasdianah. H, R. (2014). Mengenal Diabetes Melitus Pada Orang Dewasa Dan Anak-Anak Dengan Solusi Herbal. Nuha Medika. Yogyakarta.

Isdiany, N dan Rosmana, D. (2017). Indeks Glikemik, Beban Glikemik dan Asupan Energi Berperan Dalam Pengendalian Kadar Glukosa Darah Penderita Diabetes Melitus tipe 2. Jurnal Riset Kesehatan Poltekkes Depkes Bandung. Volume 7, Nomor 1. Bandung

Jelantik, G. M. I dan Haryati, E. (2014). Hubungan Faktor Resiko Umur, Jenis Kelamin, Kegemukan dan Hipertensi Dengan Kejadian Giabetess Melitus Tipe II di Wilayah Kerja Puskesmas Mataram. Media Bina IImiah. Volume 9, Nomor 1. Mataram

Kurniadi, H dan Nurrahmani, U. (2014). Stop! Diabetes Hipertensi Kolesterol Tinggi 
Jantung Koroner. Istana Medika. Yogyakarta.

Lampung

Mayawati, H dan Isnaeni, F, N. (2017). Hubungan Asupan Makanan Indeks Glikemik Tinggi Dan Aktifitas Fisik Dengan Kadar Glukosa Darah Pada Penderita Diabetes Mellitus Tipe II Rawat Jalan Di RSUD Karanganyar. Jurnal Kesehatan. Volume 10, Nomor 1. Surakata

Nursam. Lestari, H \& Afa, J. R. (2017). Analisis Hubungan Activity Of Daily Living (ADL), Aktivitas Fisik Dan Kepatuhan Diet Terhadap Kadar Glukosa Darah Pasien Diabetes Melitus Di Wilayah Kerja Puskesmas Poasia Tahun 2017. Jurnal Ilmiah Mahasiswa kesehatan Masyarakat. Volume 2, Nomor 7. Kendari

Permatasari, S. M. Sudargo, T. Purnomo, L. B. (2015). Estimasi asupan indeks glikemik dan beban glikemik dengan kontrol gula darah penderita diabetes melitus tipe 2. Jurnal Gizi Klinik Indonesia. Volume 12, Nomor 2. Yogyakarta

Pusat Kesehatan Masyarakat Ranotana Weru . (2017). Profil Puskesmas Ranotana Weru. Puskesmas Ranotana Weru

Selma Avianty, Fitriyono Ayustaningwarno. (2016). Indeks glikemik snack bar ubi jalar kedelai hitam sebagai alternatif makanan selingan penderita diabetes melitus tipe 2

Suiraoka, P. (2012). Penyakit Degeneratif Mengenal, Mencegah Dan Mengurangi Faktor Resiko 9 Penyakit Degeneratif. Nuha Medika. Yogyakarta.

World Health Organization. (2016). Global Health Obsevatory Data. www.who.int. diakses tanggal 2 Maret 2017. 